\title{
PENGARUH PEMBERIAN TABLET TAMBAH DARAH (TTD) DAN JUS JAMBU BIJI MERAH TERHADAP PENINGKATAN KADAR HEMOGLOBIN PADA REMAJA PUTRI
}

\author{
THE EFFECT OF GIVING BLOOD ADDED TABLET AND JAMUOUS SEEDS OF RED SEEDS TO INCREASING LEVELS \\ OF HEMOGLOBIN IN TEEN
}

\author{
Oktarina Listiani*), Susi Tursilowati², Ria Ambarwati²
}

\begin{abstract}
Background : Anemia experienced by most young women in Indonesia. Supplementation of Fe tablet is given to young women in junior high and high school. The absorption of Fe tablet will be maximal if consumed along with vitain C. Guava juice is one of the fruit that contains vitamin $C$ and become an alternative in increasing hemoglobin levels.
\end{abstract}

Objective : To know the effect of supplementation of Fe tablet and red guava juice to increase hemoglobin level in female adolescent at SMP PGRI 01 Semarang.

Method : This study uses Experimental Quasy with pre and post test design group control design. The number of research samples are 28 people consist of 14 treatment samples and 14 control samples. Data collected were general characteristics data of sample, anthropometric data, nutrient intake data (energy, protein, iron and vitamin C) and measurement data of $\mathrm{Hb}$ level. Statistical Analysis using Anova Repeated Measur with 95\% confidence degree.

Results : The mean hemoglobin level in the treatment group was $10.7 \mathrm{~g} / \mathrm{dL}$, in the control group of $10.2 \mathrm{~g} / \mathrm{dL}$. While the mean hemoglobin level after giving intervention in the form of supplementation of Fe tablet and guava juice in the treatment group had 11,4 gr / dL average, in control group 10,6 gr / d L which was only given Fe tablet supplementation.

Conclusion : There were no significant differences but there was an increase between hemoglobin levels before and after supplementation of Fe tablets and guava juice in the treatment group and control group $p=0.728$ ( $p$ $<0.005)$, although it was controlled with adequate intake of energy, protein, vitamin $C$, iron and long menstruation.

Keywords : Fe tablet supplementation; Hb level increase ; Red guava juice

\section{ABSTRACT}

Latar Belakang : Anemia gizi besi dialami oleh sebagian besar remaja putri di Indonesia. Program pemberian suplementasi tablet Fe diberikan kepada remaja putri di SMP dan SMA. Penyerapan tablet Fe akan lebih maksimal apabila dikonsumsi bersamaan dengan vitain C. Jus jambu biji merah merupakan salah satu buah yang mengandung vitamin $\mathrm{C}$ dan menjadi alternatif dalam meningkatkan kadar hemoglobin .

Tujuan : Untuk mengetahui pengaruh pemberian suplemtasi tablet Fe dan jus jambu biji merah terhadap peningkatan kadar hemoglobin pada remaja putri di SMP PGRI 01 Semarang.

Metode : Penelitian ini menggunakan Quasy Eksperimental dengan rancangan pre dan post test control group design. Jumlah sampel penelitian yaitu 28 orang terdiri dari 14 sampel perlakuan dan 14 sampel kontrol. Data yang dikumpulkan yaitu data karakteristik umum sampel, data antropometri, data asupan zat gizi ( energi, protein, zat besi dan vitamin C) dan data pengukuran kadar Hb. Analisis Statistik menggunakan Anova Repeated Measur dengan derajat kepercayaan 95\%.

Hasil : Rerata kadar hemoglobin pada kelompok perlakuan yaitu 10,7 gr/dL, pada kelompok kontrol 10,2 gr/dL. Sedangkan rerata kadar hemoglobin setelah diberikan intervensi berupa suplementasi tablet Fe dan jus jambu biji merah pada kelompok perlakuan memiliki rerata 11,4 gr/dL, pada kelompok kontrol 10,6 gr/dL yang hanya diberikan suplementasi tablet Fe. 
Kesimpulan : Terdapat perbedaan yang tidak signifikan namun ada peningkatan antara kadar hemoglobin sebelum dan sesudah diberikan Suplementasi tablet Fe dan jus jambu biji merah pada kelompok perlakuan dan kelompok kontrol $p=0,728$ ( $p<0,005)$, walaupun sudah dikontrol dengan kecukupan asupan energy, protein, vitamin C, zat besi dan lama haid.

Kata kunci : Suplementasi tablet Fe ; Peningkatan kadar $\mathrm{Hb}$; Jus jambu biji merah

\section{PENDAHULUAN}

Anemia gizi besi merupakan penyebab anemia terbanyak diseluruh dunia, terutama di Indonesia yang disebabkan oleh kekurangan zat besi. Dimana wanita memiliki resiko yang lebih tinggi terutama pada remaja putri ${ }^{1}$. Anemia pada remaja putri di kota Semarang tahun 2015 masih merupakan masalah kesehatan masyarakat karena prevalensinya lebih dari 15\%. Berdasarkan laporan Hasil Penjaringan Kesehatan Peserta Didik Dinas Tingkat SMP / MTs Kesehatan Kota Semarang prevalensi anemia tertinggi pada remaja tahun 2016 terdapat di wilayah kerja puskesmas Gayamsari, Kecamatan Gayamsari yaitu dengan prevalensi sebesar $40,7 \%{ }^{2}$.

Tingginya prevalensi anemia gizi besi pada remaja putri disebabkan oleh beberapa faktor diantaranya meningkatnya kebutuhan asupan zat. Selain itu rendahnya asupan zat besi dan zat gizi lainnya seperti vitamin A, C, asam folat, riboplafin dan $B 12^{3}$. Remaja wanita membutuhkan zat besi yang digunakan untuk mengganti zat besi yang hilang bersama darah menstruasi, semakin lama seseorang mengalami menstruasi maka semakin banyak zat besi yang hilang yang mengakibatkan anemia ${ }^{4}$. Berdasarkan penelitian Gunatmaningsih (2007) menunjukkan bahwa remaja wanita di SMA Negeri 1 Kecamatan Jatibarang, Kabupaten Brebes yang sedang mengalami menstruasi mempunyai resiko 1,842 kali lebih besar untuk mengalami kejadian anemia .

Upaya yang dilakukan oleh pemerintah yaitu dengan melakukan program pemberian Tablet Tambah Darah (TTD) yang diberikan kepada remaja putri usia 12-18 tahun di Institusi Pendidikan seperti SMP dan SMA atau yang sederajat dan Wanita Usia Subur ( WUS ) usia 1519 tahun di Institusi tempat kerja. Cara pemberian TTD adalah 1 ( satu ) tablet per minggu dan pada masa haid diberikan 1 tablet per hari selama 10 hari 5,6 .

Selain itu upaya lain dengan perbaikan kebiasaan makan yaitu merubah pola makan dengan pemenuhan zat besi dan zat gizi mikro seperti vitamin C, mineral dan fitokimia ${ }^{7}$. Menurut studi pendahuluan yang telah dilakukan dari 15 siswi yang diwawancarai mengenai kebiasaan makan 11 dari 15 siswi mempunyai rata - rata asupan zat besi $<80 \%$ dai AKG dan 9 dari 15 siswi mempunyai rata - rata asupan vitamin $\mathrm{C}<80 \%$ dari AKG. Tubuh memiliki kemampuan terbatas dalam penyerapan zat besi pada makanan. Penyerapan zat besi dari asupan makanan dapat dipengaruhi oleh vitamin C. Penyerapan Fe bersamaan dengan mengkonsumsi vitamin $\mathrm{C}$ alami dari buah - buahan lebih efektif dibandingkan bersamaan dengan mengonsumsi tablet Vitamin $\mathrm{C}$ dosis tinggi ${ }^{8}$. Salah satu buah sumber vitamin $\mathrm{C}$ adalah jambu biji merah.

Jambu biji merah (Psidium Guava, Linn) memiliki kandungan vitamin $\mathrm{C}$ yang termasuk tinggi yaitu dalam 100 gram jambu biji merah mengandung $87 \mathrm{mg}$ vitamin $\mathrm{C}$ dan 0,26 mg zat besi. Kandungan vitamin $\mathrm{C}$ nya dua kali lebih tinggi dari buah jeruk 7,9 . Untuk mempermudah dalam mengonsumsi jambu biji merah, maka perlu upaya pengolahan yaitu dengan melakukan diversifikasi olahan produk pangan seperti pembuatan jus atau sari buah. Jus atau sari buah merupakan minuman alternative yang diminati masyarakat dari berbagai golongan umur dan modern serta harga yang relative terjangkau ${ }^{10}$.

Penelitian oleh Monarrez (2011) menunjukkan bahwa pemberian jus jambu biji merah yang digunakan dapat meningkatkan kadar hemoglobin pada anak - anak di Mexico Barat dengan rata - rata peningkatan sebesar $1,1 \mathrm{~g} / \mathrm{dL}$ pada kelompok yang diberikan jus jambu biji merah dan $0,9 \mathrm{~g} / \mathrm{dL}$ pada kelompok placebo selama 10 minggu. Annisa, dkk (2016) menunjukkan bahwa ada peningkatan kadar hemoglobin sebelum dan sesudah diberikan jus jambu biji merah sebesar 1,3 $\mathrm{g} / \mathrm{dL}$ selama 7 hari pada remaja anemia dan tidak anemia.

Tujuan Penelitian ini untuk mengetahui pengaruh pemberian tablet tambah darah (TTD) dan jus jambu biji merah terhadap peningkatan kadar hemoglobin pada remaja putri di SMP PGRI 01 Semarang.

\section{METODE}

Penelitian ini termasuk penelitian di bidang gizi masyarakat yang dilaksanakan di SMP PGRI 01 Semarang. Untuk mencapai tujuan dilakukan penelitian dengan jenis penelitian yaitu Quasy Eksperimental dan rancangan pre dan post test control grup design. Pada penelitian ini, subjek yang memenuhi kriteria inklusi dikelompokkan 
menjadi 2, yaitu kelompok perlakuan (diberikan tablet tambah darah dan jus jambu biji merah) dan kelompok kontrol (hanya diberikan tablet tambah darah).Penelitian ini dilakukan di SMP PGRI 01 Semarang yang terdiri dari siswi kelas I dan II dan dilakukan selama 28 hari (April - Mei 2018). Subjek dalam penelitian ini adalah bersedia dijadikan sampel yang dinyatakan dalam informed consent, tidak sedang memerlukan pengobatan intesif, tidak sedang menstruasi dan dinyatakan anemia dimana kadar $\mathrm{Hb}<12 \mathrm{gr} / \mathrm{dL}$. Perhitungan sampel penelitian menggunakan rumus Randomized Controlled Trial ( sampel size ) ${ }^{11}$. Jumlah seluruh sampel penelitian yaitu 28 orang dengan rincian 14 orang pada sampel perlakuan dan 14 orang pada kelompok kontrol.

Kelompok perlakuan dalam penelitian ini diberi tablet tambah darah $1 x$ per minggu dan jus jambu biji merah setiap hari selama 4 minggu. Sedangkan pada kelompok kontrol hanya diberikan tablet tambah darah $1 \mathrm{x}$ per minggu selama 4 minggu. Kandungan dalam 1 tablet tambah darah yaitu $60 \mathrm{mg}$ zat besi dan $400 \mathrm{mcg}$ asam folat serta produk jus jambu biji merah yang terbuat dari 100 gram jambu biji merah, 1,5 sdm gula pasir dan 150 $\mathrm{ml}$ air ( setiap hari ) mengandung vitamin $\mathrm{C}$ sebesar 145,41 mg.

Variabel dependen yaitu kadar Hb sampel yang dinyatakan dalam satuan $\mathrm{gr} / \mathrm{dL}$ menggunakan metode $\mathrm{Hb}$ meter dilakukan pada sebelum treatmen dan setelah treatmen yaitu pada hari ke 29 oleh mahasiswa analis kesehatan poltekkes semarang. Variabel lain berupa status gizi berdasarkan IMT /U dalam z-score dari hasil pengukuran BB yang diukur menggunakan timbangan digital dan TB yang dikur menggunakan microtoice., lama haid, asupan zat gizi berupa energi, protein, zat besi, vitamin $\mathrm{C}$ dengan metode recall $3 \times 24$ jam yang diperoleh dengan cara membandingkan asupan dengan AKG 2013 menurut jenis kelamin dan kelompok umur, pemberian tablet tambah darah serta pemberian jus jambu biji merah.

Instrumen yang digunakan terdiri dari formulir daya terima produk, folmulir skrining, folmulir inform consent, folmulir karakteristik umum sampel, data laboratorium, folmulir recall $3 \times 24$ jam, folmulir pemantauan minum tablet tambah darah dan folmulir pemantauan minum jus jambu biji merah.

Analisis data terdiri dari analisis univariat dilakukan untuk deskripsikan karakteristik sampel dan karakteristik masing - masing variable yang diteliti yaitu status gizi, lama haid, kategori kecukupan asupan zat gizi ( energri, protein, zat besi dan vitamin C), asupan zat gizi ( energi, protein, zat besi dan viamin $\mathrm{C}$ ) serta kadar $\mathrm{Hb}$. Analisis bivariat digunakan untuk mengetahui perbedaan kadar $\mathrm{Hb}$ pada kelompok perlakuan sebelum dan sesudah treatment menggunakan uji Wilcoxon, perbedaan kadar $\mathrm{Hb}$ pada kelompok kontrol sebelum dan sesudah treatment menggunakan uji Wilcoxon, serta selisih kadar $\mathrm{Hb}$ pada kelompok perlakuan dan kelompok sebelum dan sesudah treatment menggunakan uji Independent t-test. Analisis multivariat digunakan untuk mengetahui hubungan antara variabel Independent yaitu pemberian tablet tambah darah (TTD) dan jus jambu biji merah dengan variabel Dependent yaitu kadar hemoglobin, yang dikontrol dengan asupan energi, protein, zat besi, vitamin C dan lama haid. Teknis analisis data yang digunakan pada penelitian ini yaitu dengan menggunakan uji Anove Repeated Measure, dimana hasil yang diterima adalah tidak ada perbedaan yang signifikan.

\section{HASIL DAN PEMBAHASAN}

Penelitian ini dilaksanakan di SMP PGRI 01 Semarang berlangsung selama 4 minggu dimulai tanggal 5 April- 2 Mei 2018. Jumlah sampel pada awal sampai akhir penelitian adalah 28 orang, yang terdiri dari 14 orang kelompok perlakuan dan 14 orang kelompok kontrol.

\section{a. Analisis Daya Terima Produk Jambu Biji Merah}

Uji daya terima yang dilakukan terdiri atas penilaian warna, aroma, rasa, tekstur, porsi dan secara keseluruhan oleh panelis agak terlatih yang berjumlah 20 orang, yaitu murid SMP PGRI 01 Semarang. Hasil analisis dapat dilihat pada Gambar 1.

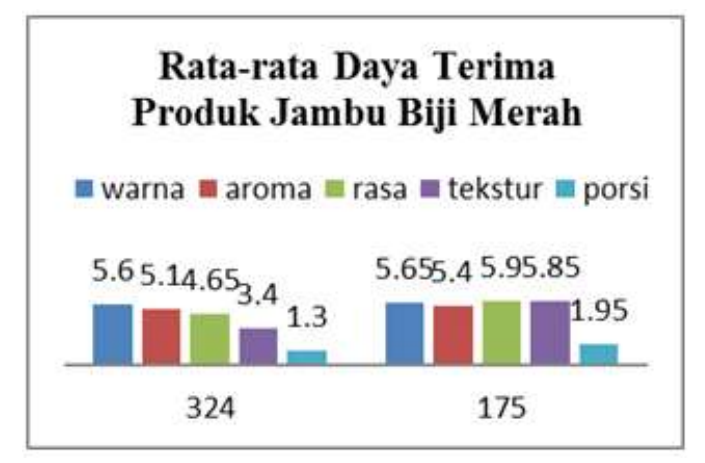

Gambar 1. Rata-rata Skor Daya Terima Produk Jambu Biji Merah

Berdasarkan gambar 1 menunjukkan bahwa produk jambu biji merah yang paling disukai oleh panelis dan akan diberikan sebagai produk penelitian dari semua aspek penilaian adalah produk dengan nomer sampel 175 (jus 
jambu biji merah) dengan nilai rata-rata skor 4,95 .

\section{b. Karakteristik Sampel Penelitian}

Distribusi karakteristik sampel penelitian menunjukkan bahwa sebagian besar sampel penelitian memiliki status gizi normal, sebanyak 13 sampel (92,9\%) pada kelompok perlakuan dan sebanyak 11 sampel (78,6\%) pada kelompok kontrol. Sampel penelitian yang menunjukkan proporsi terendah memiliki status gizi gemuk pada kelompok perlakuan yaitu sebanyak 1 sampel (7,1\%) dan pada kelompok kontrol memiliki status gizi kurang sebanyak 1 sampel (7,1\%).

Karakteristik sampel penelitian berdasarkan lama haid menunjukkan bahwa sebagian besar sampel penelitian memiliki kategori lama haid normal ( $>8$ hari) pada kelompok perlakuan yaitu 8 sampel $(57,1 \%)$, sedangkan memiliki kategori lama laid tidak normal pada kelompok kontrol yaitu 10 sampel (71,4\%). Hasil analisis dapat dilihat di Tabel 1.

Tabel 1. Distribusi Karakteristik Sampel Penelitian Berdasarkan Status Gizi dan Lama Haid Pada Kelompok Perlakuan dan Kontrol di SMP PGRI 01 Semarang

\begin{tabular}{lcccc}
\hline \multirow{2}{*}{ Variabel } & \multicolumn{3}{c}{ Kelompok } \\
\cline { 2 - 5 } & \multicolumn{2}{c}{$\begin{array}{c}\text { Perlakuan } \\
(\mathbf{n}=\mathbf{1 4})\end{array}$} & \multicolumn{2}{c}{$\begin{array}{c}\text { Kontrol } \\
(\mathbf{n}=\mathbf{1 4})\end{array}$} \\
\cline { 2 - 5 } & $\mathrm{N}$ & $\%$ & $\mathrm{~N}$ & $\%$ \\
\hline Status Gizi & & & & \\
Kurus & 0 & 0 & 1 & 7,1 \\
Normal & 13 & 92,9 & 11 & 78,6 \\
Gemuk & 1 & 7,1 & 2 & 14,3 \\
\hline Lama Haid & & & & \\
Normal & 8 & 57,1 & 4 & 28,6 \\
Tidak normal & 6 & 42,9 & 10 & 71,4 \\
\hline
\end{tabular}

Status gizi kurang menjadi salah satu faktor yang menyebabkan remaja mengalami anemia. Sesuai dengan teori yang dikemukakan oleh Sunita (2010), bahwa status gizi kurang zat - zat gizi penting salah satunya adalah zat besi tidak terpenuhi dengan baik dimana zat besi merupakan salah satu komponen terpenting dalam pembentukan hemoglobin, dengan berkurangnya bahan pembentuk sel darah merah, sehingga sel darah merah tidak dapat melakukan fungsinya dalam mensuplai oksigen yang akan mengakibatkan terjadinya anemia 12,13. Namun pada dasarnya status gizi menggunakan IMT/U bergantung pada BB dan
TB, sementara asupan nutrisi yang sesungguhnya tidak dapat dipastikan ${ }^{14}$.

Remaja putri setiap bulannya akan mengalami menstruasi. Pada umumnya menstruasi akan berlangsung setiap 28 hari selama \pm 7 hari. Lama perdarahan sekitar 3-5 hari dengan jumlah darah yang hilang sekitar 30-40 cc ${ }^{14}$. Beberapa penelitian menunjukkan bahwa jumlah darah yang hilang selama satu periode menstruasi berkisar antara 20-25 cc . Jumlah darah 20-25 cc menunjukkan kehilangan zat besi sebesar $12,5-15 \mathrm{mg} /$ bulan atau kira kira sama dengan 0,4-0,5 mg perhari. Jika jumlah tersebut ditambah dengan kehilangan basal maka jumlah total zat besi yang hilang sebesar $1,25 \mathrm{mg}$ per hari ${ }^{15}$. Namun menurut Depkes (2008), rata - rata jumlah darah yang hilang selama menstruasi adalah $60 \mathrm{ml}$ perbulan yang sama dengan $30 \mathrm{mg}$ besi, sehingga wanita terutama remaja putri memerlukan tablet tambah darah $1 \mathrm{mg}$ per hari agar keseimbangan tetap terjaga. Semakin lama seseorang mengalami menstruasi akan menyebabkan kekurangan darah sehingga semakin banyak zat besi yang hilang bersama dengan darah menstruasi yang akan mengakibatkan rendahnya kadar hemoglobin dan kejadian anemia ${ }^{4}$.

\section{c. Distribusi Kecukupan Zat Gizi}

Distribusi kecukupan zat gizi yang dikonsumsi oleh sampel penelitian meliputi kecukupan energi, protein, zat besi dan vitamin $\mathrm{C}$ diperoleh melalui metode recall $3 \times 24$ jam dan hasil recall diterjemahkan ke dalam nutrisurvey. Dimana hasilnya menunjukkan bahwa tingkat kecukupan energi terbanyak memiliki kecukupan energi defisit yaitu sebanyak 13 sampel (92,9\%) untuk kelompok perlakuan maupun kontrol. Sedangkan terendah memiliki tingkat kecukupan kurang yaitu sebanyak 1 sampel $(7,1 \%)$ baik kelompok perlakuan maupun kontrol.

Tingkat kecukupan protein menunjukkan bahwa sampel penelitian terbanyak memiliki kecukupan protein defisit yaitu sebanyak 9 sampel ( 64,3\%) untuk kelompok perlakuan dan sebanyak 12 sampel ( $85,7 \%$ ) untuk kelompok kontrol. Sedangkan terendah memiliki tingkat kecukupan kurang yaitu sebanyak 5 sampel ( $35,7 \%$ ) pada kelompok perlakuan dan sebanyak 1 sampel ( $7,1 \%$ ) serta 1 sampel (7,1\%) memiliki asupan protein sedang pada kelompok kontrol,

Tingkat kecukupan zat besi menunjukkan bahwa tingkat kecukupan zat besi 
sampel penelitian menurut umur dan jenis kelamin berdasarkan AKG 2013 sebagian besar memiliki kecukupan zat besi baik yaitu sebanyak 14 sampel ( $100 \%$ ) untuk kelompok perlakuan maupun kelompok kontrol.

Tingkat kecukupan vitamin C menunjukkan bahwa tingkat kecukupan vitamin C sampel memiliki kecukupan vitamin C baik yaitu sebanyak 14 sampel ( $100 \%$ ) untuk kelompok perlakuan karena pemberian jus jambu biji merah dan pada kelompok kontrol terbanyak memiliki tingkat kecukupan kurang yaitu sebanyak 14 sampel ( $100 \%$ ) karena tidak diberikan jus jambu biji merah. Hasil analisis dapat dilihat pada tabel 2 .

Tabel 2. Distribusi Karakteristik Sampel Penelitian Berdasarkan Kategori Kecukupan Energi, Protein, Zat Besi dan Vitamin C Pada Kelompok Perlakuan dan Kontrol di SMP PGRI 01 Semarang Tahun 2018

\begin{tabular}{|c|c|c|c|c|}
\hline \multirow{3}{*}{ tners: } & \multicolumn{4}{|c|}{ Kelampak } \\
\hline & \multicolumn{2}{|c|}{$\begin{array}{l}\text { Perlabaan } \\
\{n=14\}\end{array}$} & \multicolumn{2}{|c|}{$\begin{array}{l}\text { Kontrol } \\
(n=14)\end{array}$} \\
\hline & N & $\%$ & N & s \\
\hline \multicolumn{5}{|l|}{ Kecukupan Energ: } \\
\hline Defisit $(\leq 600)$ & 13 & 92,9 & 13 & 92,9 \\
\hline Kurang (60-6959) & 1 & 2,1 & 1 & 7,1 \\
\hline Sedang ( $79-79 \%)$ & 0 & 0 & 0 & 0 \\
\hline Heik $\{>800)$ & a & 0 & 0 & $a$ \\
\hline \multicolumn{5}{|l|}{ Kecukupan protein } \\
\hline Defeit $(\leq$ 6OS6) & 9 & 64,3 & 12 & 85,7 \\
\hline Kutang (EQGOS) & 5 & 35, 7 & 1 & 7,1 \\
\hline Sedang $[73-79 \%\}$ & 0 & 0 & 1 & 7,1 \\
\hline Babs (Paos) & 0 & D & $a$ & 0 \\
\hline \multicolumn{5}{|l|}{ Kecukupan fe } \\
\hline Defiat ( 5 6016) & 0 & 0 & 0 & 0 \\
\hline Kurans ( $6060 \%$ ) & a & 0 & 0 & 0 \\
\hline Sedang $[70-798\}$ & 0 & 0 & 0 & 0 \\
\hline $\operatorname{Hok}(>80 \%)$ & 18 & 100 & 14 & 100 \\
\hline \multicolumn{5}{|l|}{ Kecukupen Vit $C$} \\
\hline Defisit $(\leq 60 \%)$ & 0 & 0 & 14 & 100 \\
\hline Kurang (co-CAS) & a & 0 & 0 & 0 \\
\hline Serfary $[70-79 \%)$ & 0 & 0 & 0 & 0 \\
\hline $00 \mathrm{0},>80 \mathrm{~B})$ & 14 & 100 & 0 & 0 \\
\hline
\end{tabular}

Selain itu, penyebab rendahnya kadar hemoglobin dalam darah adalah asupan yang tidak mencukupi. Kurangnya asupan zat besi ke dalam tubuh yang berasal dari konsumsi zat besi dari makanan sehari - hari merupakan salah satu penyebab anemia ${ }^{16,17}$.

Zat besi merupakan salah satu komponen terpenting dalam pemberntukan hemoglobin, dengan berkurangnya baham pembentuk sel darah merah, sehingga sel darah merah tidak dapat melakukan fungsinya dalam mensuplai oksigen yang akan mengakibatkan terjadinya anemia ${ }^{12},{ }^{13}$. Pangan sumber zat besi terutama zat besi heme, yang biovailabilitas tinggi sangat jarang dikonsumsi oleh masyarakat di Negara berkembang, yang kebanyakan memenuhi kebutuhan besi remaja dari produk nabati ${ }^{9}$.

Menurut penelitian Pratiwi (2016) yang menyatakan bahwa protein memiliki salah satu peran penting sebagai alat perpindahan zat besi yang ada didalam tubuh untuk pembentukan sel darah merah di sumsum tulang. Asupan protein yang kurang mengakibatkan hambatan dalam perpindahan zat besi ke sumsum tulang sehingga produksi sel darah merah terganggu sehingga meningkatkan seseorang mengalami anemia.

Tubuh memiliki kemampuan terbatas dalam penyerapan zat besi dari makanan. Berkurangnya penyerapan zat besi dari asupan makanan dapat di pengaruhi oleh vitamin C. vitamin $\mathrm{C}$ dapat meningkatkan penyerapan zat besi dalam makanan sebanyak 30\% dan meningkatkan absorpsi besi non heme sebanyak empat kali lipat ${ }^{12,18}$.

\section{d. Distribusi Asupan Zat Gizi}

Distribusi karakteristik sampel penelitian berdasarkan asupan zat gizi sebelum dan selama intervensi menunjukkan bahwa asupan energi mengalami peningkatan sebesar 68,2 kkal untuk kelompok perlakuan dan 32,2 kkal untuk kelompok kontrol, asupan protein sebesar 2,4 gram untuk kelompok perlakuan dan 1,6 gram untuk kelompok kontrol,asupan zat besi sebesar 0,75 mg untuk kelompok perlakuan dan $0,10 \mathrm{mg}$ untuk kelompok kontrol dan asupan vitamin C sebesar 130,8 mg untuk kelompok perlakuan dan 0,05 mg untuk kelompok kontrol. Hasil analisis dapat dilihat pada tabel 3.

Tabel 3. Distribusi Karakteristik Sampel Penelitian Berdasarkan Asupan Energi, protein, Zat Besi dan Vitamin C Sebelum dan Selama Intervensi Pada Kelompok Perlakuan dan Kontrol di SMP PGRI 01 Semarang Tahun 2018

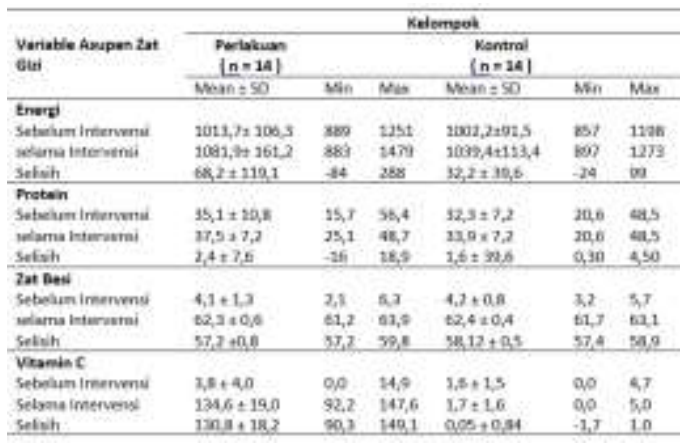

e. Kadar Hemoglobin

Karakteristik sampel penelitian berdasarkan kadar hemoglobin sebelum intervensi menunjukkan bahwa rata-rata kadar 
hemoglobin pada kelompok perlakuan yaitu $10,7 \mathrm{gr} / \mathrm{dL}$, pada kelompok kontrol 10,2 gr/dL. Sedangkan kadar hemoglobin setelah intervensi pada kelompok perlakuan memiliki rata - rata $11,4 \mathrm{gr} / \mathrm{dL}$, pada kelompok kontrol 10,6 gr/dL. Hasil analisis dapat dilihat pada tabel 4 .

Tabel 4. Karakteristik Sampel Penelitian Berdarkan Hasil Pengukuran Kadar Hemoglobin sebelum dan sesudah intervensi pada Kelompok Perlakuan dan Kelompok Kontrol di SMP PGRI 01 Semarang 2018

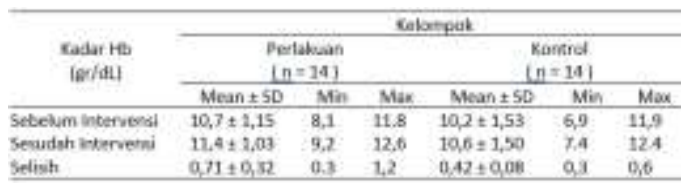

Rata - rata kadar hemoglobin sebelum dan sesuah diberikan intervensi berupa TTD $1 x$ per minggu dan jus jambu biji merah setiap hari selama 4 minggu pada kelompok perlakuan serta kelompok kontrol mengalami peningkatan, yaitu sebesar $0,71 \mathrm{gr} / \mathrm{dL}$ pada kelompok perlakuan dan pada kelompok kontrol 0,42 gr/dL. Hal ini menunjukan peningkatan kadar hemoglobin lebih besar pada kelompok perlakuan dibandingkan dengan kelompok kontrol.

f. Perbedaan Kadar Hemoglobin Sebelum dan Sesudah Intervensi antara Kelompok Perlakuan dan Kelompok Kontrol

Perbedaan kadar hemoglobin sebelum dan sesudah intervensi antara kelompok perlakuan dan kontrol menunjukkan rata-rata kadar hemoglobin sebelum intervensi pada kelompok perlakuan adalah $10,7 \pm 1,15 \mathrm{gr} / \mathrm{dL}$, sedangkan rata-rata kadar hemoglobin sebelum intervensi pada kelompok kontrol adalah 10,2 \pm $1,53 \mathrm{gr} / \mathrm{dL}$. Hasil analisis dapat dilihat pada tabel 5.

Tabel 5. Kadar Hemoglobin Sebelum dan Setelah Intervensi pada Kelompok Perlakuan dan Kelompok Kontrol di SMP PGRI 01 Semarang 2018

\begin{tabular}{|c|c|c|}
\hline \multirow{2}{*}{$\begin{array}{c}\text { Kadder itb } \\
\text { [gr/de] }\end{array}$} & \multicolumn{2}{|c|}{ Kelompck } \\
\hline & $\begin{array}{c}\text { Periakian }(n=14) \\
\text { Rato-ratat } 50\end{array}$ & $\begin{array}{l}\text { Kantrol }(n-14) \\
\text { Mata-ratarso }\end{array}$ \\
\hline Seteluen inchetwensi & $10,7 \pm 1,15$ & $10,2 \pm 1,53$ \\
\hline Sesudah intervensi & $11,4 \pm 1,03$ & $10,6+1,50$ \\
\hline p Value & 0,001 & 0,001 \\
\hline
\end{tabular}

Untuk menetahui perbedaan kadar hemoglobin sebelum dan sesudah intervensi pada kelompok perlakuan dilakukan analisis statistik menggunakan uji Wilcoxon diperoleh hasil bahwa terdapat perbedaan kadar hemoglobin sebelum dan setelah intervensi pada kelompok perlakuan, hal ini dibuktikan dengan nilai $p=0,001(p<0,05)$.

Sedangkan untuk mengetahui perbedaan kadar hemoglobin sebelum dan sesudah intervensi pada kelompok kontrol dilakukan analis statistik menggunakan uji Wilcoxon diperoleh hasil bahwa terdapat perbedaan kadar hemoglobin sebelum dan setelah intervensi pada kelompok kontrol, hal ini dibuktikan dengan nilai $p=0,001(p<0,05)$.

g. Pengaruh Pemberian Tablet Tambah Darah ( TTD ) dan Jus Jambu Biji Merah Terhadap Peningkatan Kadar Hemoglobin

Pengaruh pemberian tablet tambah darah (TTD) dan jus jambu biji merah menunjukkan rata-rata peningkatan kadar hemoglobin pada kelompok perlakuan sebesar $0,71 \pm 0,32 \mathrm{gr} / \mathrm{dL}$ dan kelompok kontrol sebesar $0,42 \pm 0,08 \mathrm{gr} / \mathrm{dL}$. Peningkatan kadar hemoglobin ada kelompok perlakuan lebih besar dibandingkan kelompok kontrol disebabkan karena pada kelompok perlakuan diberikan intervensi berupa Tablet Tambah Darah (TTD) $1 x$ per minggu dan jus jambu biji setiap hari selama 4 minggu, sedangkan pada kelompok kontrol hanya diberikan Tablet Tambah Darah (TTD) $1 \mathrm{x}$ per minggu selama 4 minggu. Hasil analisis dapat dilihat pada tabel 6 .

Tabel 6. Pengaruh Pemberian Tablet Tambah Darah ( TTD ) dan Jus Jambu Biji Merah Terhadap Peningkatan Kadar Hemoglobin antara Kelompok Perlakuan dan Kelompok Kontrol Selama Penelitian di SMP PGRI 01 Semarang 2018

\begin{tabular}{|c|c|c|c|}
\hline \multirow{2}{*}{$\begin{array}{l}\text { Kadar Hb } \\
\text { (Evidit }\end{array}$} & \multicolumn{2}{|c|}{ Kebompnk } & \multirow[b]{2}{*}{ p Wohur } \\
\hline & $\begin{array}{c}\text { Perlektuan }\{n-14\} \\
\text { Panta rata } 5 D\end{array}$ & $\begin{array}{l}\text { Kontrol in-14) } \\
\text { Pata-rata+SD }\end{array}$ & \\
\hline Sebelum intervensi & $10,7 \pm 1,15$ & $10,2 \pm 1,53$ & \\
\hline Sesuclah interversi & $11,4+1,03$ & $10.6 \div 1,50$ & \\
\hline Selnith & $0,3=0,2$ & $0,42 \div 0,08$ & 0,003 \\
\hline
\end{tabular}

Hasil Independent T-test menunjukkan ada perbedaan bermakna peningkatan kadar hemoglobin antara kelompok perlakuan dan kelompok kontrol $(p=0,003)$, hal ini menunjukkan ada pengaruh pemberian Tablet Tambah Darah (TTD) dan jus jambu biji terhadap peningkatan kadar hemoglobin pada 
remaja putri dengan anemia di SMP PGRI 01 Semarang.

Penelitian ini sejalan dengan teori yag dikemukakan oleh Proverawati (2011) yang menyatakan bahwa mengkonsumsi zat besi (Fe) bersamaan dengan vitamin $\mathrm{C}$ dapat meningkatkan penyerapan dan sangat penting dalam produksi hemoglobin.

h. Analisis Pengaruh Pemberian Tablet Tambah Darah dan Jus Jambu Biji Merah terhadap Peningkatan Kadar Hemoglobin

Analisis multivariat dengan menggunakan Anova Repeated Measure antara pemberian Tablet Tambah Darah (TTD) dan jus jambu biji merah terhadap kadar hemoglobin yang dikontrol dengan variabel asupan zat gizi dapat dilihat pada tabel 7 .

Tabel 7. Hasil analisis Anova Repeated Measure Pemberian Tablet Tambah Darah (TTD) dan Jus Jambu Biji Merah Terhadap Kadar Hemoglobin di SMP PGRI 01 Semarang 2018

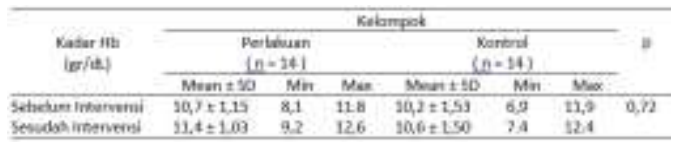

Dari hasil analisis dengan menggunakan Anova Repeated Measure pada Tabel 7 menunjukkan bahwa terdapat perbedaan yang tidak signifikan antara kadar hemoglobin sebelum dan sesudah diberikan Tablet Tambah Darah ( TTD ) dan jus jambu biji merah pada kelompok perlakuan dan kelompok kontrol $p=0,728 \quad(p>0,005)$, walaupun sudah dikontrol dengan tingkat kecukupan energy, protein, zat besi dan vitamin C serta lama haid. Perbandingan kadar hemoglobin pada kelompok perlakuan dan kontrol dapat dilihat pada Gambar 2.

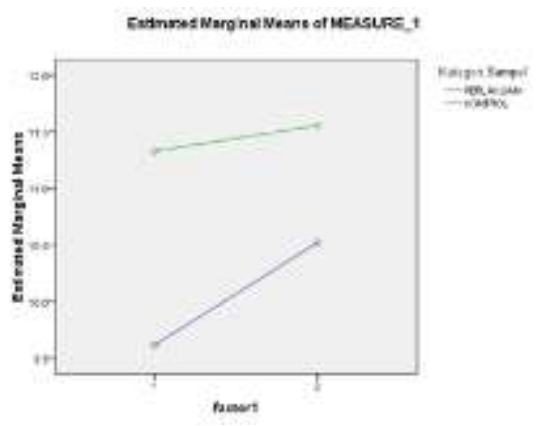

Gambar 2. Estimated Marginal Means
Dilihat pada grafik Gambar 2 terlihat bahwa terjadi peningkatan yang lebih banyak pada kelompok perlakuan dari rata-rata 10,7 $\mathrm{gr} / \mathrm{dL}$ pada pengukuran awal menjadi $11,4 \mathrm{gr} / \mathrm{dL}$ pada rata-rata pengukuran akhir atau mengalami peningkatan, dibandingkan pada kelompok kontrol yaitu terjadi kenaikan dari $10,2 \mathrm{gr} / \mathrm{dL}$ menjadi 10,4 gr/dL.

Hasil penelitian ini membuktikan bahwa dengan mengkonsumsi tablet tambah darah $1 x$ per minggu bersamaan dengan konsumsi 100 gram jambu biji merah per hari selama 4 minggu secara rutin dapat meningkatkan kadar hemoglobin pada remaja putri, karena remaja putri membutuhkan $65 \mathrm{mg}$ vitamin $\mathrm{C}$ per hari, sedangkan produk jus jambu biji merah yang diberikan kepada sampel penelitian mengandung 145,51 mg vitamin C. hasil penelitian ini sesuai dengan penelitian yang dilakukan oleh Monarrez (2011) menunjukkan bahwa pemberian jus jambu biji merah $300 \mathrm{ml}$ yang mengandung $200 \mathrm{mg}$ asam askorbat dapat meningkatkan kadar hemoglobin pada anak-anak di Mexico Barat dengan rata-rata peningkatan sebesar $1,1 \mathrm{gr} / \mathrm{dL}$ pada kelompok yang diberikan jus jambu biji merah dan 0,9 gr/dL pada kelompok placebo selama 10 minggu.

Hasil penelitian ini sejalan dengan penelitian yang dilakukan oleh Vaidyanathan ( 2016 ) yang menunjukkan bahwa ada peningkatan namun terdapat perbedaan yang tidak signifikan antara kadar hemoglobin sebelum dan sesudah mengonsumsi jus jambu biji merah dengan madu selama 45 hari dengan $p=0,452 \quad(p>0,05)$ yang didapatkan bahwa pemberian $25 \mathrm{ml}$ jus jambu biji merah dengan penambahan $5 \mathrm{ml}$ madu dimana rata - rata peningkatan 0,02 $\mathrm{gr} / \mathrm{dL}$ pada kelompok perlakuan dan -0,02 pada kelompok kontrol ${ }^{11}$.

Hasil penelitian ini juga sejalan dengan penelitian yang dilakukan oleh Zarianis ( 2006 ) dimana ada perbedaan yang tidak signifikan terhadap perubahan kadar hemoglobin pada kelompok perlakuan dan kelompok kontrol setelah diberikan sumplemen besi dan vitamin $C$ dengan $p=0,75$, rata - rata peningkatan kadar $\mathrm{Hb}$ pada kelompok perlakuan । 1,53 gr/dL sedangkan pada kelompok perlakuan II 1,40 $\mathrm{gr} / \mathrm{dL}$. Namun penelitian ini tidak sejalan dengan penelitian yang dilakukan oleh Monarrez (2011) yang menunjukkan bahwa terdapat perbedaan yang signifikan antara kadar hemoglobin sebelum dan sesudah mengonsumsi jus jambu biji merah dengan $p=0,01 \quad(p<0,05)$ yang didapatkan hasil bahwa pemberian jus jambu biji merah $300 \mathrm{ml}$ setara 200 AA dengan rata - 
rata peningkatan sebesar $1,1 \mathrm{gr} / \mathrm{dL}$ pada kelompok perlakuan dan 0,9 $\mathrm{gr} / \mathrm{dL}$ pada kelompok kontrol ${ }^{19}$.

Jambu biji merah merupakan salah satu buah yang mengandung vitamin $C$ yang tinggi ${ }^{20}$. Fiastuti Witjaksono mengatakan bahwa efektifitas penyerapan Fe bersamaan dengan mengonsumsi vitamin C alami dari buah buahan lebih baik dibandingkan penyerapan $\mathrm{Fe}$ bersamaan dengan mengonsumsi tablet Vitamin C dosis tinggi 7,8 . Menurut Satria Perdana, vitamin C lebih baik didapatkan secara langsung dari buah dan sayur karena merupakan sumber alami, namun jika asupan dari buah dan sayur kurang maka perlu mengonsumsi suplemen yang mengandung vitamin C. selain buah dan sayur adalah sumber alami, vitamin $\mathrm{C}$ dalam buah lebih bertahan lama. Penelitian yang dilakukan oleh Fiastuti (2017) pada mencit (tikus kecil) memperlihatkan, vitamin $\mathrm{C}$ bertahan lebih lama di jaringan bila diberikan dari buah dibandingkan dari suplemen. Para peneliti membuktikan, setiap 2 hari sampai 1 minggu, meski menurun drastis, kadar vitamin $\mathrm{C}$ mencit masih lebih tinggi dibandingkan yang diberikan suplemen. Dokter Fiastuti memaparkan, meskipun kita mengonsumsi sampai 1.000 mg vitamin C, bukan berarti ia akan bertahan selama 10 hari. Vitamin $\mathrm{C}$ akan dikeluarkan dari tubuh setiap harinya, jadi akan pecuma bila mengonsumsi banyak vitamin $\mathrm{C}$, bahkan lewat suplemen. Vitamin $\mathrm{C}$ yang dikonsumsi melalui buah - buahan akan bertahan lebih lama dibandingkan vitamin $\mathrm{C}$ yang didapatkan dari suplemen ${ }^{3}$.

Tabel 8. Analisis Pengaruh Kecukupan Energi, Protein, Vitamin C, Zat Besi dan Lama Haid terhadap Selisih Perubahan Kadar Hemoglobin Sebelum dan Sesudah Intervensi Sampel Penelitian di SMP PGRI 01 Semarang 2018

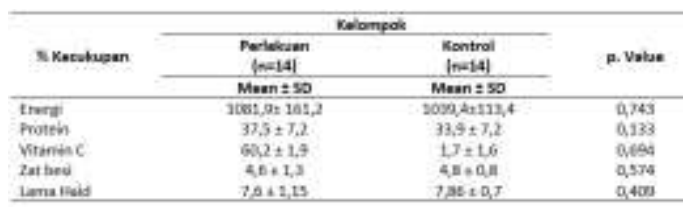

Hasil uji Anova Repeated Measure menunjukkan bahwa tingkat kecukupan energi, protein, vitamin $\mathrm{C}$ dan zat besi serta lama haid tidak berpengaruh terhadap peningkatan kadar hemoglobin.

\section{KESIMPULAN DAN SARAN}

\section{KESIMPULAN}

Berdasarkan hasil penelitian, maka dapat ditarik kesimpulan bahwa terdapat perbedaan yang tidak signifikan antara kadar hemoglobin sebelum dan sesudah diberikan Tablet Tambah Darah ( TTD ) dan jus jambu biji merah pada kelompok perlakuan dan kelompok kontrol $p=0,728 \quad(p>0,005)$, walaupun sudah dikontrol dengan tingkat kecukupan energy, protein, zat besi dan vitamin C serta lama haid.

\section{SARAN}

Saran dalam penelitian ini yaitu pemberian Tablet Tambah Darah (TTD) dan jus jambu biji dapat digunakan sebagai salah cara dalam upaya mengatasi masalah anemia pada remaja putri, perlu dilakukan penelitian serupa dengan menambahkan kebiasaan lama haid pada kriteria inklusi serta menghomogenkan sampel penelitian agar tidak terdapat kerancuan selama proses dan hasil penelitian dan perlu dilakukan penelitian serupa dengan menggunakan alat ukur pengambilan darah melalui vena untuk hasil yang lebih teliti.

\section{DAFTAR PUSTAKA}

1. Kemenkes R.I. Profil Kesehatan Indonesia. Jakarta; 2013.

2. Dinkes Kota Semarang. Laporan Hasil Penjaringan Kesehatan Peserta Didik Tahun 2016. Semarang; 2016.

3. Hartriyanti dan Triyanti. Gizi dan Kesehatan Masyarakat. Departemen Gizi dan Kesehatan Masyarakat Universitas Indonesia, editor. Jakarta: PT Raja Grafindo Persada; 2007.

4. Gunatmaningsih D. Faktor-Faktor Yang Berhubungan Dengan Kejadian Anemia Pada Remaja Putri Di Sma Negeri 1 Kecamatan Jatibarang Kabupaten Brebes Tahun 2007. 2007;

5. Almatsier S. Gizi Dalam Daur Kehidupan. Jakarta: Penerbit Buku Kedokteran EGC; 2009.

6. RI KK. Pemberian Tablet Tambah Darah Untuk Remaja Putri dan Wanita Usia Subur. 2016.

7. Annisa N dkk. Media Farmasi Indonesia Vol 12 No 1 Media Farmasi Indonesia Vol 12 No 1. 2016;12(1):1150-5.

8. Dep. Gizi dan kesehatan Masyarakat Fak. Kesmas UI. Gizi dan Kesehatan Masyarakat. Jakarta: PT Raja Grafindo Persada; 2010.

9. USDA. Guava ( Psidium guajava ) Fresh, Nutritive Value per 100 g. 2013.

10. Afani F. Pengaruh Perbandingan Jambu Biji 
(Psidium Guajava L.) Dengan Rosella (Hibiscus Sabdariffa Linn) Dan Jenis Jambu Biji Terhadap Karakteristik Jus Tugas. 2016;

11. Reeta R, Vaidyanathan R. a Study To Compare the Effectiveness of Gooseberry Juice With Honey Versus Ripe Guava Juice With Honey on the Level of Haemoglobin Among Adolescent Girls With Anaemia Studying in Selected Schools At Dharmapuri Dist, Tamil, Nadu. Int J Pharma Bio Sci. 2016;7(3):959-62.

12. Ramzi, M., Haghpanah, S., Malekhmakan, L., Cohan, N., Baseri, A. Z. Anemia and Iron Deficiency in Adolescent Scool Girl in Kavar Urban Area, Southern Iran. 2011;2:123-33.

13. Sayoga S. Gizi Remaja Putri. Jakarta: EGC; 2006.

14. Moyudan M, Publikasi N. Hubungan Status Gizi Dengan Kejadian Anemia Pada Remaja Putri Di Smk Sleman Yogyakarta Anemia Pada Remaja Putri Di Smk Muhammadiyah 1
Moyudan. 2017;

15. Arisma M, editor. Gizi Dalam Daur Kehidupan. 2nd ed. Jakarta: EGC; 2010.

16. Arisman. Gizi dalam Daur Kehidupan. Jakarta: Penerbit Buku Kedokteran EGC; 2004. 171 p.

17. Khomsan A. Pangan dan Gizi untuk Kesehatan 2. Bogor; 2005.

18. Megabohari. Anemia Saat Menstruasi [Internet]. 2011. [cited 2018 Jan 5]. Available from: http://megabohari@yahoo.com

19. Monárrez-Espino J, López-Alarcón M, Greiner T. Randomized Placebo-Controlled Trial of Guava Juice as a Source of Ascorbic Acid to Reduce Iron Deficiency in Tarahumara Indigenous Schoolchildren of Northern Mexico. J Am Coll Nutr. 2011;30(3):191-200.

20. USDA. Guava (psidium guajava) Fresh, Nutritive Value per 100 g. In 2013. 